A. M. A ksiutenko, Y u. P. Y efymov, R. A. Kantserova, M. V. Petrushenko, T. H. Smila

\title{
Experimental system for studying the effect of the arrangement of nonhermetic module fillers on the outgassing flow density
}

\author{
Institute of Technical Mechanics \\ of the National Academy of Sciences of $U$ kraine and the State Space Agency of U kraine \\ 15 Leshko-Popel St., Dnipro 49005, U kraine; e-mail: smelaya.t.g@ nas.gov.ua
}

In recent years, components and materials of industrial and commercial quality have been in frequent use in the assembly of small spacecraft to reduce the cost of space projects. This may affect spacecraft and onboard equipment reliability and performance quality. In particular, a high risk may arise from unpredictable performance characteristics of components and materials of this type caused by outgassing flows of unregulated density. The situation is aggravated by difficulties in numerical simulation of the complex internal geometry of actual nonhermetic small spacecraft. The most efficient way to resolve this problem is to conduct laboratory tests.

This paper presents an experimental system for studying the dependence of degassing processes on the geometry of arrangement of electronics boards and various structural materials in a nonhermetic module. The theoretic basis for experiments is a differential realization of the accumulation method, which allows one to differentiate the density of degassing flows from particularly arranged specimens and elements of the module's inner surface.

To reproduce the design features of nonhermetic nano- and picosatellites, models of nonhermetic modules were refined, and a special laboratory module was made on their basis. For this purpose, a unit of synchronous module evacuation control was updated, equipment was developed for positioning plate-type fillers of nonhermetic modules, the recording of gas-dynamic parameters of a nonhermetic module's own internal atmosphere was provided, and an automated experiment control system was prepared. The laboratory module was integrated into the automated measuring system of the VAU-2M vacuum aerodynamic installation of the Institute of Technical Mechanics of the National Academy of Sciences of Ukraine and the State Space Agency of Ukraine. The experimental system developed was tested to show a satisfactory operability of both its components and the system as a whole.

The system developed allows one to study outgassing from the surface of various components and materials, to measure the density of outgassing flows for various equipment arrangements, and to study the dynamics of outflow of the products of the own internal atmosphere through calibrated orifices, which simulate the outflow of the own internal atmosphere of a nonhermetic module through its unregulated clearances.

Keywords small spacecraft, nonhermetic module models, fillers, electronics plates, arrangement, flat channels, outgassing, own internal atmosphere, outgassing flow density.

1. Aksiutenko A. M., Kantserova R. A. Design features of nonhermetic small spacecraft. 11-th Ukrainian Conference on Space Research, August 29 - September 2, 2011, Yevpatoria, Crimea, Ukraine. Kyiv. 2011. P. 123. (in Ukrainian).

2. Tumanov A. V., Zelentsov V. V., Shcheglov G. A. Basics of Spacecraft Onboard Equipment Arrangement. Moscow: Bauman Moscow State Technical University, 2017. 572 pp. (in Russian).

3. Aksyutenko A. N., Bass V. P., Brazinsky V. I., Dotsenko O. V., Solodovnik L. L., Tarasov V. B., Yarmak A. D. Experimental and numerical study of gas-dynamic processes in spacecraft's nonhermetic modules. Teh. Meh. 1999. No. 2. Pp. 13-24. (in Russian).

4. Bass V. P. Molecular Gas Dynamics and its Applications to Space Technology. Kyiv: Naukova Dumka, 2008. 269 pp. (in Russian).

5. Akishin A. I., Dunaev N. M., Konstantinova V. V. Spacecraft's own atmosphere and its effect on the onboard devices and technology in space. Space Material Science and Technology. Moscow: Nauka, 1977. Pp. 65-77. (in Russian).

6. Akishin A. I., Dunaev N. M., Konstantinova V. V., Rastorguev V. A., Savchenko S. A., Simonov A. N., Kamyshkov S. A., Konanykin L. V., Popov Yu. A., Yashin S. V. Spacecraft-produced atmosphere and its effect on onboard equipment operability. Space Model. S. N. Vernov (Ed.). Moscow: NIIYa FMGU, 1983. V. 2. Pp. 244-309. (in Russian).

7. Danilin V. A. Own external atmosphere of space vehicles and its influence on parameters of radio signals of on-board radio systems. Thermophysics and Aeromechanics. 2008. V. 15. No.1. Pp. 69-71. https://doi.org/10.1134/S0869864308010058 
8. Testoedov N. A., Kochura S. G., Maksimov I. A. System for monitoring the levels of space environment exposure experienced by satellites developed by "Information Satellite Systems" Company. Vestnik SibGAU. 2015. V. 16. No. 4. Pp. 849-856. (in Russian).

9. Smirnov V. A., Nadiradze A. B., Maksimov I. A., Khartov V. V., Shatrov A. K. et al. Study of the contaminating action of the own external atmosphere and the plasma of the stationary plasma engines on the Express-AM spacecraft. Vestnik SibGAU. 2006. No. 2(9). Pp. 46-50. (in Russian).

10. Nadiradze A. B., Smirnov V. A., Maksimov I. A., Khartov V. V., Tibil'deeva V. V. Experimental study of the contaminating action of a spacecraft's own external atmosphere at the orbital operation stage. Vestnik SibGAU. 2006. No. 1(8). Pp .91-95.

11. Nadiradze A. B., Shaposhnikov V. V., Khartov V. V., Maksimov I. A., Ivanov V. V., Smirnov V. A. Simulation of the formation of a spacecraft's own external atmosphere and the contamination of its surface. Space Model. V. 2. Exposure of Spacecraft Material and Equipment to the Space Environment. Moscow: KDU, 2007. Pp. 39-59. (in Russian).

12. Silver D. M. Modeling of spacecraft contamination outgassing as a diffusion-controlled process. Proc. Optical System Contamination: Effects, Measurement, Control III (San Diego, US, 18 December 1992). 1992. p. $37-45$.

https://doi.org/10.1117/12.140750

13. Hässig M., Altwegg K., Balsiger H., Schläppi B., Berthelier J. J., Fiethe B., Fuselier S. A., De Keyser J., Rubin M. Investigation of spacecraft outgassing by sensitive mass spectrometry. Spectroscopy Europe. 2011. V. 23. Pp. 20-23.

14. Anwar A., Elfiky D., Gamal H., Albona M., Marchetti M. Outgassing effect on spacecraft structure materials. International Journal of Astronomy, Astrophysics and Space Science. 2015. V. 2. No. 4. Pp 34-38.

15. Zilong Jiao, Lixiang Jiang, Jipeng Sun, Jianguo Huang, Yunfei Zhu. Outgassing environment of spacecraft: an overview. IOP Conf. Series: Materials Science and Engineering. 2019. Pp. 1-8.

16. Campbell W. A., Scialdone J. J. Outgassing data for selecting spacecraft materials. NASA Reference Publication 1124, Revision 3. Washington: NASA, 1993. $436 \mathrm{pp}$.

17. Nadiradze A. B., Ivanov V. V., Maksimov I. A., Khartov V. V., Smirnov V. A. Mathematical simulation of the contamination of spacecraft's outer surfaces by electrojet engine exhausts and the components of the own external atmosphere. IVth International Aerospace Congress: abstracts. August 18-23, 2003, Moscow. Pp. 200-201. (in Russian).

18. Nadiradze A. B., Shaposhnikov V. V., Lukyanets R. V., Korsun A. G., Kurshakov M. Yu., Tverdokhlebova E. M. Program for Calculating the Parameters of the Own Eternal Atmosphere of a Geostationary Spacecraft with Electrojet Engines. SVI-ERD. FAP RKT. Registration Number 4144. 2010. (in Russian).

19. Nadiradze A. B., Chirov A. A., Shaposhnikov V. V., Smirnov V. A., Maksimov I. A. Estimation of the degassing time of a spacecraft's nonhermetic instrument module. Vestnik SibGAU. 2007. No. 14. Pp. 95-98. (in Russian).

20. Testoedov N. A., Smirnov V. A. Study of the dependence of the degree of effect of the own atmosphere and the plasma generated by the stationary plasma engines on the spacecraft layout. Vestnik of Samara University. Aerospace and Mechanical Engineering. 2009. No. 2. Pp. 24-32. (in Russian).

21. Abramovskaya M. G., Aksyutenko A. N., Bass V. P., Yefimov Yu. P., Pecheritsa L. L., Solodovnik L. L., Yarmak A. D. Experimental studies in rarefied gas dynamics. Teh. Meh. 2002. No. 2. Pp. 45-57. (in Russian).

22. Nusinov M. D. Effect and Simulation of Space Vacuum. Moscow: Mashinostroyeniye, 1982. 175 pp. (in Russian). 
23. Aksyutenko A. N., Kantserova R. A. Laboratory setup for the study of gas-dynamic processes in models of spacecraft's nonhermetic modules. 10th Ukrainian Conference on Space Research, August 30 - September 3, 2010, Yevpatoria, Crimea, Ukraine. Kyiv, 2010. Pp. 74. (in Russian).

24. Abramovskaya M. G., Aksyutenko A. N., Bass V. P., Yefimov Yu. Laboratory and full-scale experiments on the study of gas-dynamic processes in the vicinity of spacecraft and on their surface. Space Model. V. 2. Exposure of Spacecraft Materials and Equipment to the Space Environment. Moscow: KDU, 2007. Pp. 60-116. (in Russian).

25. Aksyutenko A. N., Kantserova R. A. Laboratory module for studying the formation of the own atmosphere in models of small spacecraft's modules. All-Russian Conference on Current Problems in Rarefied Gas Dynamics. Novosibirsk, 2013. Pp. 15-17. (in Russian).

26. Aksyutenko A. N. Automated system for rarefied gas pressure measurement in models of spacecraft's nonhermetic modules. Teh. Meh. 2004. No. 2. Pp 50-55. (in Russian).

27. Vacuum Technology: Handbook. K. E. Demikhov, Yu. V. Panfilov (Eds.). Moscow: Mashimostroyeniye, 2009. 590 pp. (in Russian).

28. Vacuum Technology: Handbook. E. S. Frolov, V. E. Minaichev (Eds.). Moscow: Mashimostroyeniye,1992. 480 pp. (in Russian).

29. Rosebury A. F. P. Handbook of Electron Tubes and Vacuum Techniques. Moscow: Energiya, 1972. 456 pp. (in Russian).

30. Rozanov L. N. Vacuum Technology. Moscow: Vysshaya Shkola, 1982. 207 pp. (in Russian).

31. Zuev D. M., Pyatkov A. G., Movchan P. V., Smirnov D. V., Kostyukov A. S. SIBCUBE - CubeSat satellite project of SibSAU student. Vestnik SibGAU. 2014. No. 4(56). Pp. 160-166. (in Russian).

32. Danilkin A. P., Kozlov V. A. World trends in the development of small satellites. Ekonomicheskiye Strategii. 2016. No. 6. Pp. 136-149. (in Russian).

33. CubeSat. NTUU "KPI" Research laboratory - 2015. URL: http://www.cubesat.org.ua/ua/. Last accessed on September 29, 2020.

34. Aksiutenko A. N., Kantserova R. A. Device for simulating some features of fillers of small spacecraft's nonhermetic modules. 5th Ukrainian Conference on Space Research, August 24-28, 2015 Odesa, Ukraine. Kyiv, 2015. P. 75. (in Ukrainian). 